DEPARTMENT OF THE INTERIOR

UNITED STATES GEOLOGICAL SURVEY

GEOLOGIC MAP AND LIGNITE DEPOSITS OF THE DENGATE QUADRANGLE, MORTON COUNTY, NORTH DAKOTA

By C. S. Venable Barclay 


\title{
GEOLOGIC MAP AND LIGNITE DEPOSITS OF THE DENGATE QUADRANGLE, MORTON COUNTY, NORTH DAKOTA
}

\author{
By C. S. Venable Barclay
}

\section{INTRODUCTION}

The Dengate quadrangle is an area of approximately 51 square miles in western Morton County, southwestern North Dakota. The quadrangle is about 40 miles west of Bismarck, the State capitol (fig. 1), and about 3.5 miles east of Glen Ullin (population 1,087). Interstate Highway 94 , U.S. Highway 10 , and the tracks of the Burlington Northern, Inc. (formerly Northern Pacific Railroad) cross the northern part of the area.

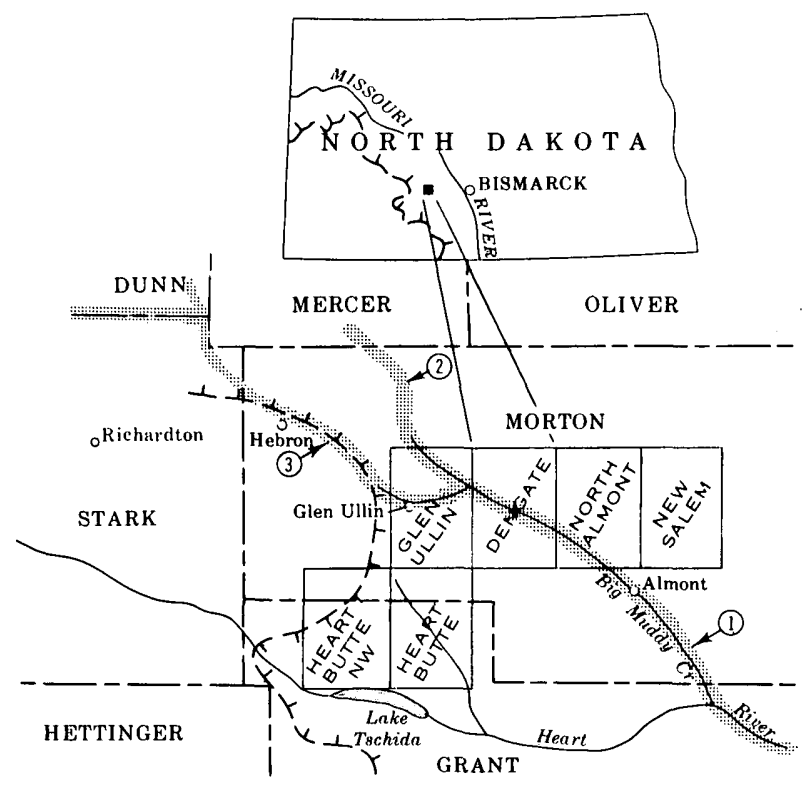

Figure 1. Index map showing the location of the Dengate and other $7 \frac{1}{2}-$ minute quadrangles in North Dakota being mapped by the U.S. Geological Survey. Hachured dashed lines show the outermost drift border of Wisconsin age as mapped by Colton, Lemke, and Lindvall (1963). Approximate positions of the Pleistocene Muddy Creek (1), Elm Creek (2), and South Fork (3) trenches as mapped by Benson (1953) are shown by shading.

The Dengate quadrangle is one of a group of several adjoining $7 \frac{1}{2}$-minute quadrangles that are being mapped by the U.S. Geological Survey to furnish a basis for classification of lands withdrawn by the Federal Government pending classification for coal and to contribute to the geologic map atlas of the United States.
During the summer of 1966, the U.S. Geological Survey conducted a drilling program in the Dengate and nearby quadrangles (Smith, 1970) to gather information on the existence, thickness, and depth of lignite beds in withdrawn Federal lands. Two of the holes drilled are in the Dengate quadrangle.

\section{PHYSIOGRAPHY}

The Dengate quadrangle is in the Missouri Plateau section of the Great Plains physiographic province (Fenneman, 1931, p. 61). The area contains rolling prairies, numerous sandstone hills and buttes, the broad Curlew Valley, and steep-sided buttes in which lignite beds of the Fort Union Formation have burned and the overlying sediments have been baked to form a resistant rim or cap rock. Locally, dissection of clayey parts of the Fort Union Formation has produced badland topography.

The principal stream in the area is Big Muddy Creek, an underfit stream in the Curlew Valley which flows southeastward across the quadrangle and joins the Heart River, a tributary of the Missouri River, about 17 miles southeast of the quadrangle.

The climate of the area is semiarid. The winters are long and severe; the summers are short and hot.

Some of the area is under cultivation for grain; the rest generally has a cover of prairie grass. Brush and deciduous trees grow along watercourses and in small patches on some slopes in hilly terrain.

\section{STRATIGRAPHY}

The Tongue River and Sentinel Butte Members of the Fort Union Formation of Paleocene age underlie most of the surface. The Fort Union is locally covered by Pleistocene glacial drift or Holocene alluvium. A geologic map of the area and a generalized stratigraphic section of the Fort Union are presented on sheet 1. Stratigraphic sections measured in the Fort Union in the quadrangle and nearby areas are shown graphically on sheet 2 .

\section{TERTIARY ROCKS \\ FORT UNION FORMATION}

The Paleocene Fort Union Formation in North Dakota consists of the Ludlow, Cannonball, Tongue River, and Sentinel Butte Members (Brown, 1962, p. 11). The Ludlow, a continental deposit, is the basal unit of the Fort Union in southwestern North Dakota where it overlies the Upper Cretaceous Hell Creek Formation; it intertongues with the marine Cannonball (Brown, fig. 1). The Tongue River and the overlying Sentinel Butte are continental deposits and are exposed over most of western North 
Dakota (Carlson, 1969). In southwestern North Dakota the Sentinel Butte Member is locally overlain by the Golden Valley Formation (late Paleocene and early Eocene) (Hickey, 1969), by the White River Formation (Oligocene), or by Quaternary deposits.

A total of 445-495 feet of the Tongue River and Sentinel Butte Members is exposed in the Dengate quadrangle. The closest exposures of the base of the Fort Union, the contact between the Cannonball or Ludlow and the Hell Creek Formation, are 20-25 miles southeast of the quadrangle in southeastern Morton County (Laird and Mitchell, 1942, pl. I; Carlson, 1969). The nearest exposures of the contact between the Golden Valley Formation and the Sentinel Butte Member are shown by Carlson (1969) to be about 10 miles north of Gien Ullin.

That part of the Fort Union exposed in the Dengate quadrangle is composed of weakly indurated very thinly to thickly interbedded sandstone, siltstone, mudstone, and claystone, numerous beds of carbonaceous shale and of lignite, and a small amount of limestone. Sandstone also occurs in very thick lenticular beds that locally cut out thick sections of the other rock types. The colors of most rocks in the formation range from light shades of gray, yellow, and olive to darker shades of gray, olive gray and greenish gray. The sandstone is generally light colored, silty, very fine grained, and friable. Sandstone in thick lenticular channel-filling deposits is mostly fine grained and locally has thin conglomeratic lenses containing rounded pebbles of claystone or siltstone and angular fragments of ferruginous nodules. The siltstone is generally clayey and is light or moderately dark colored, depending on the clay content. The claystone is commonly dark and silty. Silty claystone and clayey siltstone are the most abundant rock types in the formation. Many of the rocks in the formation are classified as mudstone, a term used for a massive rock that contains at least 50 percent clay and silt but in which the relative amounts of silt and clay are unknown. Thin beds of brownish-gray to dark-grayish-brown carbonaceous shale are common, and carbonaceous claystone, mudstone, and (or) shale are generally associated with lignite beds.

Limestone in the formation is dense and brownish gray and weathers yellowish orange; it occurs exclusively in discoidal pods that are commonly 1-3 feet thick and 3-8 feet in diameter. Lines of limestone pods crop out at several stratigraphic horizons in the Tongue River but are rare in the Sentinel Butte. In gross aspect most of the limestone pods appear to be concretions, but they could be primary deposits (Royse, 1970, p. 55).

A Tongue River limestone pod 11/2-2 feet thick that crops out 5 feet above the ys marker bed near the $\mathrm{C} \mathrm{N} 1 / 2$ sec. 15, T. 138 N., R. 87 W., was sampled and studied in detail. The pod is composed of dense brownish-gray limestone capped by a few inches of reddish-brown ferruginous silty limestone containing numerous fragments of fossil snails. In thin section the limestone primarily consists of a groundmass of very fine grained calcite that contains many scattered grains of quartz and iron oxide, much lesser amounts of feldspar, pyrite, and muscovite, and rare grains of chlorite, dolomite(?), zircon, and sphene(?). Samples from the lower part (D-10a-1, -2), upper part (D-10b, 10b-1), and top (D-10c-1, -2) of the pod and representative samples (D-16, D-48, and D-60) of three other limestone pods were analyzed for $\mathrm{Ca}, \mathrm{Mg}$, $\mathrm{Fe}$, and $\mathrm{Mn}$ (table 1). Samples D-16 and D-48 are from about the same stratigraphic level as the D-10 series; sample D-60 is from the upper part of the Sentinel Butte Member at Twin Buttes in the northwestern part of the quadrangle. Samples D-48 and D-60 are petrographically similar to samples D-10a-1 and $-2, \mathrm{D}-10 \mathrm{~b}$, and D-10b-1. Sample D-16 contains much more quartz, feldspar, mica, and chlorite and is better stratified than the other samples. Diffractograms of each of the samples show the $2.9 \AA$ peak of dolomite. Sample D-16 contains at least 10 percent dolomite.

TABLE 1. - $\mathrm{Ca}, \mathrm{Mg}, \mathrm{Fe}$, and $\mathrm{Mn}$ content (percent) of limestone pods in the Tongue River and Sentinel Butte Members of the Fort Union Formation, Dengate quadrangle

[Analyses for $\mathrm{Ca}, \mathrm{Mg}$, and $\mathrm{Fe}$ by titration methods; for $\mathrm{Mn}$ by spectrophotometer. Results for $\mathrm{Ca}$ and $\mathrm{Mg}$ are accurate within \pm 3 percent. Analyst: R. F. Gantnier, U.S. Geological Survey]

\begin{tabular}{|c|c|c|c|c|c|c|c|}
\hline Sample No. & Acid soluble & Total carbonate & $\mathrm{Ca}$ & $\mathrm{Mg}$ & $\mathrm{Fe}$ & Mn & $\begin{array}{c}\mathrm{Ca} / \mathrm{Mg} \\
\text { (molal ratio) }\end{array}$ \\
\hline D-10a-1 & 75.95 & 68.34 & 26.63 & 0.51 & 2.81 & $<0.1$ & 31.69 \\
\hline D-1 0a-2 & 76.25 & 70.09 & 27.23 & .58 & 2.42 & $<.1$ & 29.48 \\
\hline D-10b & 76.30 & 69.95 & 26.73 & .90 & 2.52 & $<.1$ & 18.02 \\
\hline D-10b-1 & 75.55 & 71.27 & 27.62 & .64 & 2.10 & $<.1$ & 26.19 \\
\hline D-1 0c-1 & 63.40 & 54.50 & 21.09 & .51 & 10.05 & .2 & 25.10 \\
\hline D-1 0c-2 & 63.20 & 54.24 & 20.89 & .58 & 9.35 & .2 & 21.86 \\
\hline${ }^{1} \mathrm{D}-16$ & 71.15 & 62.25 & 23.33 & 1.13 & 2.14 & .0 & 12.53 \\
\hline${ }^{2} \mathrm{D}-48$ & 80.70 & 74.64 & 28.90 & .69 & 1.95 & .0 & 25.42 \\
\hline${ }^{3} \mathrm{D}-60$ & 78.05 & 71.33 & 27.74 & .57 & 1.57 & .4 & 29.53 \\
\hline
\end{tabular}

${ }^{1}$ From NW1/4NW1/4 sec. 34, T. 139 N., R. 87 W.

${ }^{2}$ From NE $1 / 4$ SW $^{1 / 4}$ sec. 16, T. 138 N., R. 87 W.

${ }^{3}$ From SW1/4SW1/4 sec. 18, T. 139 N., R. 87 W. 
Carbonate and clay minerals are the predominant cementing materials in most rocks of the formation. Insoluble-residue analyses of 181 samples - 54 from that part of the Tongue River above the ys marker (generalized stratigraphic section, sheet 1) and 127 from the Sentinel Butte - from outcrops of clastic rocks in the Glen Ullin and Dengate quadrangles were made by R. F.

Gantnier, U.S. Geological Survey. The results of these determinations show that material soluble in about $4 \mathrm{~N}$ $\mathrm{HCl}$ ranges from 3 to 30 percent in about 90 percent of the samples and 30 to 76 percent in 10 percent of the samples. Samples containing more than 50 percent acidsoluble material are from resistant limy sandstone lenses in sandstone beds. Thin sections of several such samples show extensive replacement of matrix material by calcite.

Siliceous cement, commonly opal, was found by diffractometer and thin-section studies in samples from beds of various types of resistant carbonaceous rocks in the Sentinel Butte Member in the Dengate and Glen Ullin quadrangles. In one sample - a silty sandstone or siltstone containing rootlet or stem molds, the matrix consisted of heulandite-clinoptilolite(?) in addition to opal, quartz, and clay mineral (Barclay, 1973). Thin sections of silicified carbonaceous shale, a locally abundant rock of the Sentinel Butte, show replacement of most of the original material of the rock by very fine grained calcedonic quartz and opal.

Pyrite is commonly found as monomineralic nodules and in concretions in many rocks of the formation and also occurs as grains and irregularly shaped masses replacing matrix material in some sandstone and siltstone. Locally resistant limonitic layers generally about 1 inch thick form dark-yellowish-orange bands in some exposures of claystone-siltstone and, less commonly, in clayey laminae in sandstone. Before oxidation most of these layers were probably thin beds and lenticles of very limy pyritic claystone and (or) of nodular pyritic limestone such as were seen in core samples from Geological Survey drill holes (Barclay, 1973). Crystals of gypsum and, in a core sample from the drill hole in sec. 18, T. $139 \mathrm{~N}$., R. 87 W., barite were found in some rocks of the Fort Union. At least some of the gypsum was probably derived from the oxidation of iron sulfide nodules (Barclay, 1973).

Tongue River Member. - About 180-220 feet of the upper part of the Tongue River is exposed in the Dengate quadrangle. Along part of the Heart River valley in northern Grant County 15-20 miles south of Glen Ullin, Tisdale (1941, p. 10-11, pl. 1) mapped the contact between the Cannonball and Tongue River Members and reported that the Tongue River commonly has a basal sandstone as much as 100 feet thick. Adding Tisdale's thickness for the basal sandstone and the thickness of the stratigraphic interval between the top of the basal sandstone and various Fort Union marker beds which crop out in both the area that Tisdale mapped and the Dengate quadrangle, the total thickness of the Tongue River in the quadrangle is estimated to be at least 295-325 feet.
Reconnaissance indicates that in the region between the southern part of the Dengate quadrangle and the Heart River and between the town of Almont and Lake Tschida (fig. 1) the Tongue River Member can locally be divided into two parts informally designated units $\mathrm{A}$ and $\mathrm{B}$. The lower part, unit A, is estimated to be at least 150-210 feet thick regionally and 150-180 feet thick in most places in the Dengate quadrangle. It consists of thick light-colored lenticular sandstone beds, dark-colored mudstone and claystone, and a few lignite beds. The base of the Tongue River was not seen in the region reconnoitered, and only a portion of the upper part of unit $A$ is exposed in the quadrangle.

Near the east end of the north shore of Lake Tschida on the Heart River, the sandstone that Tisdale (1941, p. 10-12) referred to as the basal sandstone of the Tongue River forms a light-gray to light-yellowish-gray cliff and is about 185 feet below the top of the Tongue River Member. The tops of possible correlatives of Tisdale's basal sandstone of the Lake Tschida area were found about $225,220,195$, and 210 feet below the top of the Tongue River in drill holes in sec. 28, T. 138 N., R. 88 W., Heart Butte quadrangle (Stephens, 1970b); in sec. 32, T. 139 N., R. 88 W., Glen Ullin quadrangle (Barclay, 1973); sec. 20 , T. 138 N., R. 87 W., Dengate quadrangle; and in sec. 18 , T. 139 N., R. 87 W., Dengate quadrangle, respectively. A sandstone outcrop along a stream bank near the center sec. 14 , T. 137 N., R. 86 W., south of Almont, is the top of a sandstone that is about 175 feet below the top of the Tongue River and near the stratigraphic position of Tisdale's basal sandstone. A stratigraphic section of this outcrop is shown on sheet 2 .

An interval of thick mudstone and subordinate claystone beds that are somber shades of dark olive gray and brownish gray was seen in the upper part of unit A at several localities. The drab colors are the most distinctive characteristic of the unit. The most extensive outcrops of these beds are south of Alrnont in those parts of T. 137 N., Rs. 85 and 86 W., that are west of Big Muddy Creek and at altitudes between 1,900 and 2,100 feet (stratigraphic sections, sheet 2). Olive and brownish-gray sandy shaly mudstone beds near the top of unit $\mathrm{A}$ are exposed on the northeast bank of Big Muddy Creek in sec. 3 , T. 138 N., R. 87 W., Dengate quadrangle (strat. sec. 33, sheet 2), and on the northeast side of Heart Butte Creek in secs. 27 and 34, T. 137 N., R. 88 W., Heart Butte quadrangle.

Locally thick lignite and carbonaceous beds are a common feature of the upper part of unit A. On the north side of Lake Tschida a thick lignite bed with a thin mollusk coquina bed above is locally well exposed above the top of the basal sandstone and was mapped by Stephens (1970a, b) as the Shell lignite. Lignite beds $2.5-4$ feet thick that occur 152-190 feet below the top of the Tongue River in Geological Survey drill holes in the Dengate and Glen Ullin (Barclay, 1973) quadrangles and Hancock's (1921, pl. V) A bed are believed to be in the upper part of unit A and near the position of Stephens' Shell lignite bed. 
A persistent thin lignite or carbonaceous shale bed that commonly has a very thin locally pyritic coquina of snail and small clam shells in the roof claystone generally occurs at the top of unit $A$ in the Dengate quadrangle where it was mapped and informally named the ys marker bed for the yellow siltstone of the basal beds of the overlying unit B. The ys marker was traced into the North Almont quadrangle where it is what $\mathrm{H}$. L. Smith (oral commun., May 20, 1971) in the $W^{1} \frac{1}{2}$ sec. 4, T. 138 N., R. 86 W., called the Crooked Creek lignite bed. At an altitude of about 2,095 feet on a hill on the east side of Sims Creek in the NE1/4 sec. 14, T. 138 N., R. 86 W., New Salem quadrangle, rocks typical of the basal part of unit B rest on a thin lignite bed that is probably equivalent to the ys marker. At the locality near Sims Creek and south of Almont in T. 137 N., Rs. 85 and 86 W., the ys marker appears to be what Hancock $(1921$, p. 32, 35, and pl. V) mapped as the B bed. Hancock (p. 13) put the New Salem lignite field B bed about 100 feet above the Cannonball, but in the area that he mapped south of Almont he may have included some sandstone near the base of the Tongue River in the Cannonball. On the north side of Lake Tschida a lignite bed subjacent to rocks typical of the basal beds of unit B of the Tongue River and believed to be equivalent to the ys marker crops out 70-90 feet above Tisdale's (1941, p. 11-13) basal sandstone and was mapped by Stephens $(1970 \mathrm{a}, \mathrm{b})$ as the Koehler lignite bed.

The location of the ys marker bed in the subsurface is difficult to determine from drill hole samples. The ys marker bed is probably the thin lignite bed that was intersected about 96.5 feet below the top of the Tongue River in the drill hole in sec. 20, T. 138 N., R. 87 W., and about 145 feet below the top in the drill hole in sec. 18, T. 139 N., R. 87 W. The lignite bed that Stephens (1970b) showed about 165 feet below the top of the Tongue River in the drill hole in sec. 28, T. 138 N., R. 88 W., Heart Butte quadrangle, may be equivalent to the ys marker bed of the Dengate quadrangle.

In many places the dark-colored fine-grained rocks typical of the upper part of unit A are largely replaced by thick lenticular sandstone beds. In the Lake Tschida area, Tisdale (1941, p. 12) reported 42 feet of sandstone about 30 feet above the basal sandstone. A massive sandstone more than 40 feet thick that contains some very thin siltstone or mudstone beds near the top crops out in this interval on the north side of Scab Creek in the SE $1 / 4 \mathrm{NW}^{1 / 1} / 4$ sec. 23 , T. $138 \mathrm{~N}$., R. $87 \mathrm{~W}$., in the southeastern part of the Dengate quadrangle. A thick sandstone sequence in the upper part of unit $A$ is well exposed in the bluffs bordering Curlew Valley just south of Almont and may be the sandstone that Hennen (1943, p. 1580) identified as the Almont sandstone and mistakenly correlated with the basal sandstone of the Tongue River.

Unit B of the Tongue River Member is 95-160 feet thick in the Dengate quadrangle and consists of a lower sequence of clayey siltstone, mudstone, and subordinate sandstone and an upper sequence of siltstone and sandstone. The lower part of unit B is commonly about 80 feet thick, although the range in thickness is $45-115$ feet. It is marked at the base by a pale-yellow or golden interval, commonly 20-30 feet thick, of locally fossiliferous clayey siltstone, a few thin ripple-marked sandstone beds, and some limestone pods. Fossil materials are snails, small clams, and plant remains (mostly leaves). The distinctive pale-yellow basal interval is conspicuous on some of the buttes south of Almont in T. 137 N., Rs. 85 and 86 W., where it is in sharp color contrast to the drab-colored beds of the underlying unit $A$.

The Tavis Creek bed, a locally thick lignite bed which seems to split into two beds as much as 20 feet apart in some places, occurs at the top of the lower part of unit B. The interval between the pale-yellow strata at the base of unit B and the Tavis Creek bed consists generally of olivegray to pale-olive clayey siltstone and mudstone, some light-olive-gray to yellowish-gray sandstone, at least one conspicuous level of limestone pods, and a few thin lignite beds. Thick lenticular channel-filling sandstone beds occur locally in the lower part of unit B and form prominent outcrops along the northeast side of Big Muddy Creek in the SE1/4NE $1 / 4$ sec. 3, T. 138 N., R. 87 W., in the Dengate quadrangle and along the northeast side of Heart Butte Creek in the SW $1 / 4 \mathrm{SE}^{1 / 4} \mathrm{sec}$. $27, \mathrm{~T} .138 \mathrm{~N}$., R. $88 \mathrm{~W}$., in the Heart Butte quadrangle.

The upper part of unit B of the Tongue River ranges in thickness from 10 to 40 feet but is generally $20-30$ feet thick. It is locally well exposed and is composed predominantly of dusky-yellow clayey siltstone and , yellowish-gray sandstone. Limestone pods crop out in the upper part. The basal beds are composed mostly of olive-gray to pale-olive silty claystone; similar beds at the top generally contain one or two very thin $(<1-2$ in.) lignite or carbonaceous shale seams. In some places a lignite bed 4-8 inches thick that contains white-weathering silicified wood slabs and large tree stumps crops out at the top of unit B and may be equivalent to the HT Butte lignite, a thick lignite bed which occurs at the top of the Tongue River in parts of western North Dakota (Royse, 1967, p. 5).

Fossil mollusks were collected in the Dengate and Heart Butte NW quadrangles from the upper part of unit $\mathbf{A}$ and from the distinctive pale-yellow interval of rocks at the base of unit B. A list of the fossils is presented in table 2 . D. W. Taylor of the U.S. Geological Survey (written commun., Aug. 15 and 22, 1966) described all the fossils that he identified as fresh-water middle Paleocene forms, although he also suggested that Corbula cf. C. crassatelliformis (Meek and Hayden) may have tolerated both brackish and fresh water.

Samples of carbonaceous rocks in core recovered from holes drilled in the Sentinel Butte and Tongue River Members in sec. 18, T. 139 N., R. 87 W., and in sec. 20, T. 138 N., R. 87 W., were collected for palynological correlations of lithologic units mapped in the field. R. H. Tschudy of the U.S. Geological Survey (written commun., June 26, 1968), after a detailed qualitative and quantitative palynological study of the samples, made the following observations: 
"1. The species comprising the pollen and spore flora show few qualitative changes in the Tongue River and Sentinel Butte.

"2. Prominent quantitative changes are observed at successive levels in each well.

"3. These maxima and minima, or levels of abundance or lack of abundance, can be correlated between the two wells [fig. 2].

"4. These correlation horizons parallel the lithologic boundaries separating the several members [Sentinel Butte, Tongue River, and units A and B of the Tongue River] of the upper Fort Union Formation.

" 5 . The events causing the floral changes affected the floras surrounding the original deposition sites simultaneously; the correlation horizons may be considered as time-lines."

Tschudy (written commun., Dec. 16, 1966, June 26, 1968) also reported that a high percentage of TaxodiaceousCupressaceous pollen was found in all core samples and in an outcrop sample (D3818-B) of the lower part of a lignite bed locally mapped as the ys marker (strat. sec. 10, sheet 2).

Stratigraphically, the lowest sample collected in the Dengate quadrangle is D4494 from the drill hole in sec. 20 , T. 138 N., R. 87 W. This sample is from rocks about 140-145 feet below the ys marker and below lignite beds near the stratigraphic position of Stephens' (1970a, b)
Shell lignite. According to R. H. Tschudy (written commun., July 15,1970 ) it contains a pollen assemblage that suggests an early (but not earliest) or middle Paleocene age, a Lebo (but not Tullock) equivalent age. Tongue River rocks older than this have been found nearby in the northeastern part of the New Salem lignite field by Leffingwell $(1971$, p. 17) who reported that a sample from Hancock's (1921, pl. V) A lignite contains a Tullock-basal Lebo palynological assemblage, and assemblage characterized in part by the highest appearance of Kurtzipites (R. H. Tschudy, oral commun., 1970; Leffingwell, 1971, p. 14). The exact stratigraphic position of the bed that Leffingwell sampled is unknown. Hancock's (1921, p. 13) $\mathrm{B}$ bed appears to be equivalent to the ys marker in some places in the New Salem lignite field, and his A bed, which he described as generally being about 55 feet below B, should occur stratigraphically near or above the rocks of sample D4494 and have a similar pollen assemblage. It may be that the bed that Leffingwell sampled is not the bed that Hancock mapped as the A bed in other parts of the New Salem area but is a much lower bed. According to G. D. Mowat of the U.S. Geological Survey (oral commun., June 1971), the highest occurrence of Kurtzipites found by Tschudy (written commun., Aug. 31,1967 ) in samples from a drill hole in the NW1/4NW1/4NE $1 / 4$ sec. 29 , T. $137 \mathrm{~N}$., R. 90 W., Clark Butte NE quadrangle, Grant County, N. Dak., is 417-422 feet below the top of the Shell lignite in

TABLE 2. - List of fossil mollusks from the Tongue River Member of the Fort Union Formation

\begin{tabular}{|c|c|c|c|c|}
\hline $\begin{array}{l}\text { USGS } \\
\text { Cenozoic } \\
\text { locality } \\
\text { No. }\end{array}$ & Quadrangle & $\begin{array}{l}\text { Stratigraphic } \\
\text { interval }\end{array}$ & Fossils & $\begin{array}{l}\text { Identified } \\
\text { by }\end{array}$ \\
\hline M2702 & Dengate & $\begin{array}{l}4.5 \text { feet above ys(?) marker (strat. } \\
\text { sec. } 33 \text {, sheet } 2) \text {. }\end{array}$ & $\begin{array}{l}\text { Snails: } \\
\text { Bellamya leai (Meek and } \\
\text { Hayden). } \\
\text { Bellamya sp. } \\
\text { Campeloma nebrascense } \\
\text { (Meek and Hayden). }\end{array}$ & $\begin{array}{l}\text { D. W. Taylor, } \\
\text { USGS. }\end{array}$ \\
\hline M2721 & $\ldots$ do-...- & $\begin{array}{l}5 \text { feet above ys marker (strat. sec. } 4 \text {, } \\
\text { sheet 2). }\end{array}$ & $\begin{array}{l}\text { Snail: } \\
\quad \text { Campeloma nebrascensis } \\
\quad \text { (Meek and Hayden). } \\
\text { Clam: } \\
\quad \text { Corbula cf. } C \text {. } \\
\quad \text { crassatelliformis Meek }\end{array}$ & Do. \\
\hline M2704 & - - do - . . . - & $\begin{array}{l}15 \text { feet below ys(?) marker (strat. } \\
\text { sec. } 33 \text {, sheet } 2 \text { ). }\end{array}$ & $\begin{array}{l}\text { Snails: } \\
\text { Campeloma nebrascensis } \\
\text { (Meek and Hayden). } \\
\text { Cleopatra tenuicarinata } \\
\text { (Meek and Hayden). } \\
\text { Clam: } \\
\text { "Corbula" mactriformis } \\
\text { Meek and Hayden. }\end{array}$ & Do. \\
\hline D24512 & $\begin{array}{l}\text { Heart Butte } \\
\text { NW. }\end{array}$ & $\begin{array}{l}\text { 25-30 feet below Stephens' (1970a) } \\
\text { Koehler lignite bed (ys marker } \\
\text { equivalent). }\end{array}$ & $\begin{array}{l}\text { Campeloma nebrascensis } \\
\text { (Meek and Hayden). } \\
\text { Lioplacodes nebrascensis } \\
\text { (Meek and Hayden). }\end{array}$ & $\begin{array}{l}\text { N. F. Sohl, } \\
\text { USGS. }\end{array}$ \\
\hline
\end{tabular}




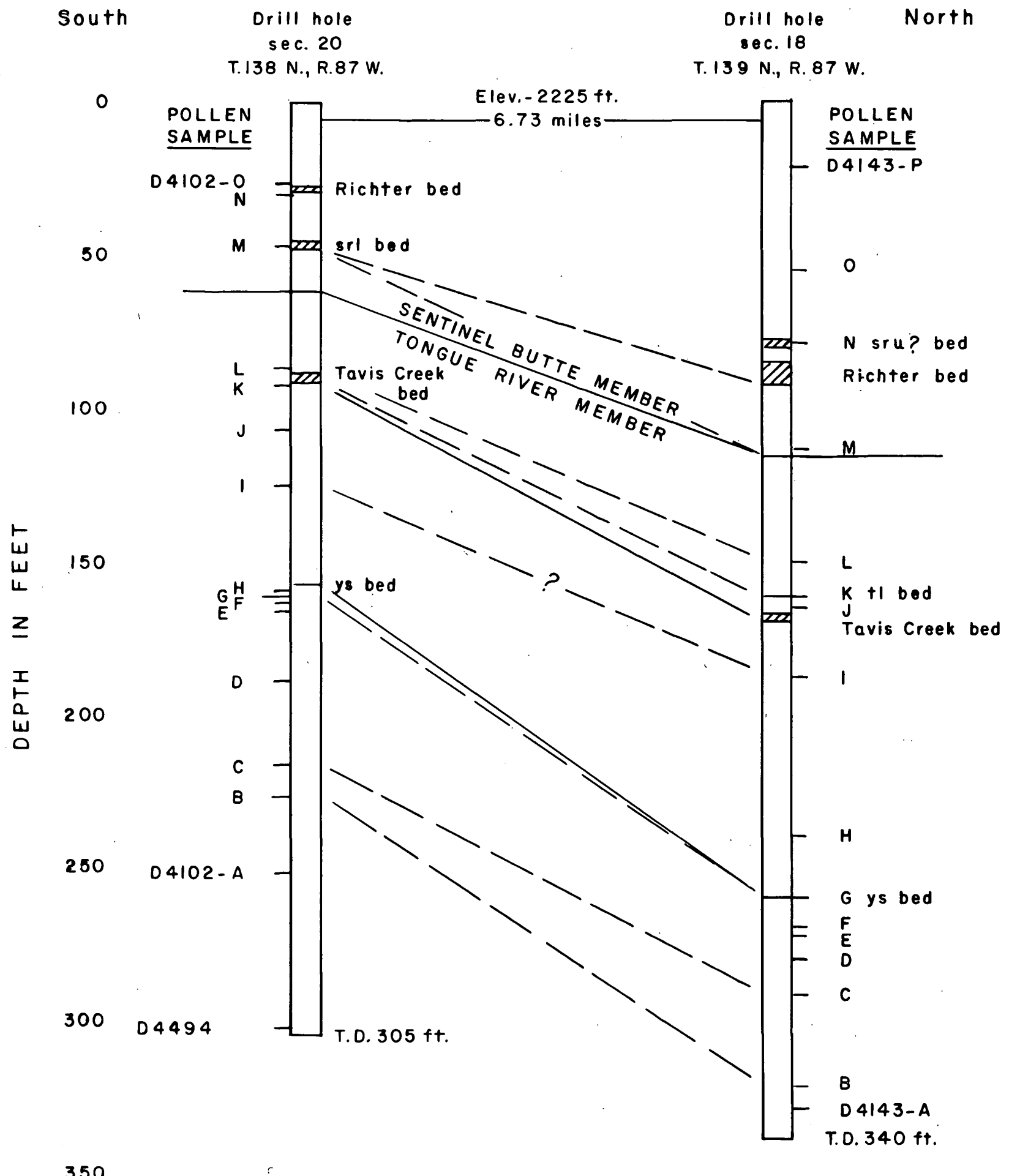

Figure 2. - Chart showing paly nological correlations of core samples of Fort Union rocks encountered in two drill holes in the Dengate quadrangle, Morton County, N. Dak. Modified from R. H. Tschudy (written commun., June 26, 1968). 
beds that could be in the Ludlow Member.

Sentinel Butte Member. - The Sentinel Butte Member, which is about 265-285 feet thick in the Dengate quadrangle, is lithologically similar to the Tongue River Member. Separation of the two members in the field, based primarily on a change from light outcrop colors below to dark outcrop colors above, is difficult except in those areas where considerable distances across the contact are exposed. The difference in the outcrop colors and other features that may be used in differentiating between the two members in western North Dakota were ably discussed by Royse $(1967,1970)$.

In the Dengate quadrangle the Sentinel Butte Member is characterized by drab-colored bentonitic mudstone and clayey siltstone beds, locally abundant white-weathering silicified carbonaceous shale, stumps, and logs, and the "mud butte" topography described by Seager and others (1942, p. 1417). These features are most conspicuous in the basal $40-60$ feet and may be mainly confined to the lower 140-170 feet of the Sentinel Butte.

For purposes of discussion the Sentinel Butte Member can be divided into three units, A, B, and C, of which only unit $A$ is well exposed. Unit $A$ is that part of the Sentinel Butte below the top of the Spring Valley-Richter lignite zone. Unit A, which is approximately 40-70 feet thick, is composed of interbedded light- and yellowishgray sandstone and sandy siltstone, light-olive-gray and pale-olive clayey siltstone, and dark-olive and greenishgray bentonitic mudstone and small amounts of brownish-gray carbonaceous mudstone or claystone, grayishbrown carbonaceous shale, lignite, and rare limestone pods. Thin beds of white-weathering silicified carbonaceous shale are fairly common and form locally mappable marker beds. Large white-weathering silicified tree stumps, logs, and wood slabs occur in some lignite and carbonaceous shale beds. The Spring Valley-Richter lignite zone at the top of unit $A$ is a zone of locally thick and persistent mappable lignite beds.

A badland, or "mud butte," topography, characterized by small round, nearly conical, and flat-topped bare buttes, is locally formed on the strata of unit A. Profiles of the buttes typically display reentrant slopes and benches at stratigraphic intervals that contain large amounts of swelling clays. The dark mudstone at the base of the Sentinel Butte commonly forms a bench that has a thick hummocky clay crust above 20-30 feet of light-colored Tongue River sandstone and siltstone which stands in fluted near-vertical walls.

Unit B is that part of the Sentinel Butte between the Spring Valley-Richter lignite zone and the ws marker bed. Unit B is about 90-1 10 feet thick, is poorly exposed, and in general appears to consist primarily of a sequence of light- and dark-colored beds similar to strata in unit $\mathrm{A}$, a few thin lignite beds, and locally thick channel-filling sandstone beds.

Unit $C$ is that part of the Sentinel Butte above the base of the ws marker bed. Unit $C$ is about 120-130 feet thick at Twin Buttes in the northwestern part of the quadrangle. At this locality unit $\mathrm{C}$ has a basal sequence of about 40 feet consisting mostly of pale-yellow clayey siltstone, yellowish-gray to nearly white weathering coarsegrained siltstone and silty sandstone containing some thin interbeds of lignite and carbonaceous shale, and, near the top, yellowish-brown siltstone (-mudstone) and thin lignite beds. A bed of brownish-black carbonaceous shale or lignite that generally occurs at the base of unit $\mathrm{C}$ is informally named the ws marker bed for the white sandstone or siltstone beds of the overlying rocks. The interval of light-colored siltstone (-sandstone) beds near the base of unit $\mathrm{C}$ is an areally persistent lithologic unit that can be seen on some high hills and buttes in the northern part of the Dengate quadrangle, in the Glen Ullin quadrangle, and farther westward (Barclay, 1973). A lignite bed at the top of the light-colored siltstone (-sandstone) sequence in the Twin Buttes area (strat. sec. 55, sheet 2) is believed to be equivalent to the beds that are burned near the top of Rocky Ridge in the southern part of the Glen Ullin quadrangle (Barclay, 1973). On the northwest butte of Twin Buttes the lignite bed is overlain by 40 feet of olivegray to dusky-yellow clayey siltstone and mudstone containing a limestone pod horizon and a thin carbonaceous shale at the top. Above the carbonaceous shale is 50 feet of yellowish-gray to pale-brown massive fine-grained sandstone that forms the cap rock of the buttes.

The contact between the Sentinel Butte and Tongue River Members in the area is at the base of the lowest bed of a sequence of alternating thick dark bentonitic mudstone or claystone beds and light-colored siltstone or sandstone beds. The dark color of the basal mudstone contrasts sharply with the uniformly light colored interval of siltstone and sandstone typical of the uppermost part of the Tongue River. The contact is exposed at many localities in the southern part of the quadrangle but is especially well displayed on some steep-sided buttes in the western parts of secs. 1 and 12 and the eastern part of sec. $11, \mathrm{~T}$. 138 N., R. 88 W., the northern part of sec. 16, T. 138 N., R. $87 \mathrm{~W}$., the southeastern part of sec. 24, T. 139 N., R. $88 \mathrm{~W}$., and the south half of secs. 16, 17, and 19 , the north half of secs. 20 and 30 , and the west half of secs. 23 and 26, T. 139 N., R. $87 \mathrm{~W}$.

The outcrop appearance of the Sentinel Butte-Tongue River contact in the Dengate quadrangle is strikingly similar to its appearance in the Twin Buttes area north of the town of Sentinel Butte and in part of the South Unit Theodore Roosevelt National Park in western North Dakota. The contact in those areas was described by Royse (1967, p. 12 and 22, figs. 4C-D and 5A-C). In many other areas of western North Dakota the contact is drawn between a locally thick lignite, the HT Butte lignite bed of the Tongue River, and a silty sandstone which is commonly several tens of feet to more than 100 feet thick (Royse, 1967, p. $5,7)$.

The contact between the members was pentrated but could not be positively identified in the U.S. Geological Survey drill holes in sec. 18, T. 139 N., R. 87 W., and sec. 20, T. 138 N., R. 87 W., Dengate quadrangle, and in sec. 10, T. 139 N., R. 88 W., Glen Ullin quadrangle (Barclay, 1973). 
Three samples collected from the interval 9-22 feet above the ws marker in the Glen Ullin quadrangle (Barclay, 1973) yielded a late Paleocene pollen assemblage (E. B. Leopold, written commun., April 10, 1972).

\section{QUATERNARY DEPOSITS}

The Quaternary deposits locally overlying beds of the Fort Union Formation with pronounced unconformity are glacial drift of Pleistocene age and alluvium of mostly Holocene age. Small unmapped landslide deposits are common on steep slopes, especially slopes formed on the basal clayey beds of the Sentinel Butte Member of the Fort Union.

\section{GLACIAL DRIFT}

As shown in figure 1 , the Dengate quadrangle is about 7 miles east of a segment of the outermost drift border of Wisconsin age as mapped by Colton, Lemke, and Lindvall (1963, fig. 1). Big Muddy Creek, which flows diagonally across the middle of the quadrangle, occupies part of the Muddy Creek trench, which was an ice-marginal diversion channel for glacial meltwater during the Pleistocene (Leonard, 1916; Benson, 1953, pl. 3). Wilson Creek, the principal tributary of Big Muddy Creek in the northern part of the quadrangle, is in a valley that was probably a meltwater channel tributary to the Muddy Creek trench (Benson, 1953, pl. 3)

Glacial drift in the quadrangle consists of free boulder erratics and sand and gravel deposits. Free boulder erratics, hereafter termed erratics, generally composed of granite, granodiorite, or gneiss, are scattered throughout the quadrangle but are most numerous south of Curlew Valley. The locations of erratics were noted on field sheets in order to ascertain the extent of drift in the quadrangle but are not shown on the map. Sand and gravel deposits occur on benches and buttes along the south side of Curlew Valley, the valleys of most of the major streams south of Curlew Valley, and the valley of Wilson Creek north of Curlew Valley. Hereafter in this report, "drift" will refer to sand and gravel deposits unless otherwise qualified.

Most of the drift in the area is in small, poorly exposed, and thin (1-5 ft thick) deposits. These deposits are chiefly composed of granule and pebble gravel and minor amounts of sand. A few of the deposits may contain boulder-size rocks; erratics are numerous on and near some deposits. The pebble fraction, which generally comprises about half of most deposits, is composed mostly of dark-reddishbrown subangular to subrounded platy and bladed fragments of ferruginous nodular layers and concretions derived from Fort Union strata. Well-rounded mudstone pellets, bladed subangular white-weathering silicified wood fragments, and subangular chips of ganister, all probably derived from the Fort Union, comprise a minor part of the pebble fraction. Generally less than 5 percent, and in some deposits less than 1 percent, of the pebble fraction is composed of well-rounded fragments of granite, granodiorite, amphibolite, various types of dark finegrained gneiss, and well-indurated sedimentary rocks such as reddish-brown siltstone, black and light-olive-brown chert, and greenish-gray siltstone and sandstone.

Areas containing numerous scattered pebbles and cobbles of the kinds common to the drift occur in many parts of the quadrangle but are most abundant in the southeastern part. Most accumulations of these pebbles and cobbles are believed to be lag deposits of the coarser fractions of drift and were not mapped.

Most of the drift shown on the geologic map is believed to be outwash and inwash(?) deposits formed during a northeastern retreat of the ice front across a segment of the Muddy Creek trench and the present-day valley of Wilson Creek. Some of the very thin deposits may be till.

\section{ALLUVIUM}

As mapped, alluvium consists of sand, silt, and clay principally derived from erosion of the Fort Union Formation and is mostly of Holocene age but may. include some glacial deposits of Pleistocene age. The Holocene alluvium in Curlew Valley is at least $30-40$ feet thick and that in Wilson Creek is probably 15-30 feet thick. Most of the alluvium mapped in the drainages tributary to Big Muddy Creek probably ranges in thickness from less than 5 to more than 25 feet. As mapped, the alluvium includes some colluvium on the sides of valleys.

The alluvium in Curlew Valley probably overlies thick glacial deposits of the former Muddy Creek trench. According to Trapp (1971, p. 376) a hole drilled in the South Fork trench, a branch of the Muddy Creek trench (fig. 1), in Stark County north of Richardton, about 39 miles west, intersected about 278 feet of Quaternary fill. In the Elm Creek trench, another branch of the Muddy Creek trench, in southern Mercer County north of Glen Ullin, a drill hole encountered 220 feet of Quaternary fill (Croft, 1970, p. 69). P. G. Randich (oral commun., Dec. 2, 1971) of the U.S. Geological Survey reported that a hole drilled in the Muddy Creek trench in sec. 9, T. 136 N., R. 85 W., Grant County, near the confluence of Big Muddy Creek and the Heart River contained about 206 feet of Quaternary sediments. Another hole drilled in the Muddy Creek trench in sec. 5 had 177 feet of Quaternary fill (Randich, oral commun., Dec. 2, 1971).

\section{STRUCTURE}

The Dengate quadrangle is on the southeastern flank of the Williston basin. In the southwestern part of the quadrangle the Fort Union strata appear to be on the north or northeast flank of a structural high in, or just south of, the Glen Ullin quadrangle (Barclay, 1973) and dip 20-40 feet per mile in a northeasterly direction. Northeast of Curlew Valley, the dip appears to flatten, and dip directions and amounts are highly variable. Local dips on some lignite beds that crop out along the sides of wide valleys appear much higher than 40 feet per mile and are probably the result of camber of the lignite beds into the valleys.

\section{ECONOMIC GEOLOGY LIGNITE}

LIGNITE BEDS AND ZONES

Lignite beds in the Fort Union Formation are shown on the geologic map and in a series of stratigraphic sections (sheet 2). Lignite beds that could be mapped over wide 
areas of the quadrangle were given informal names. The names and corresponding letter designations of beds are shown in the generalized stratigraphic section (sheet 1).

In general, all beds 1 or more feet thick were mapped. The thickest outcropping beds are 7-9 feet thick in some places. Where two or more beds were found to be so close together that it was not possible to clearly separate their traces on the geologic map, only the trace of the more persistent bed is shown.

Except for the local bed inferred in the $\mathrm{N}^{1 / 2}$ sec. 15 and the south edge of the SE $1 / 4$ sec. 10, T. 138 N., R. 87 W., no mappable lignite beds were found in outcrops below the ys marker. Lignite in single beds 2.5-4 feet thick was encountered below the ys marker in the drill holes in sec. 20 , T. 138 N., R. 87 W., and sec. 18, T. 139 N., R. 87 W. (sheet 2).

The total number of lignite beds 1 or more feet thick in that part of the Fort Union Formation above the ys marker bed in most places is estimated to be between 7 and 14. Individual lignite beds are generally lenticular, but lignite zones tend to be areally persistent. The thickest and probably the most persistent lignite beds in the area are the Tavis Creek bed in the upper part of the Tongue River Member and some of the beds of the Spring Valley-Richter lignite zone in the Sentinel Butte Member.

The Tavis Creek lignite bed is commonly 20-40 feet below the top of the Tongue River Member in the Dengate quadrangle. The thickest outcrops of this bed generally occur west of Curlew Valley where thicknesses of 5-6 feet in a single bed were measured in secs. 1 and 23 , T. 138 N., R. 88 W. Locally, instead of a single bed, two beds 1-20 feet apart crop out near the normal stratigraphic position of the Tavis Creek bed. Where the separation between the two beds is less than 10 feet, only the lower bed is mapped; it is designated the Tavis Creek bed. Where the separation is more than 10 feet, the lower bed, which invariably appears to be the thicker of the two, is mapped as the Tavis Creek bed and the upper bed is mapped as a local upper bench of the Tavis Creek bed. This local bench, which is a carbonaceous shale or thin lignite bed in some places, appears to merge with the main Tavis Creek bed in some areas of the quadrangle. The Tavis Creek bed was mapped in the Glen Ullin quadrangle (Barclay, 1973) and traced into the North Almont quadrangle. It is approximately equivalent to Stephens' (1970a, b) Beaver Creek bed and to Hancock's (1921, p. 13) $\mathrm{C}$ bed, and at Klondike Butte in the New Salem quadrangle it correlates well with the bed that Smith (1973) designated as the Cut Bank Creek bed.

The Spring Valley-Richter lignite zone is in the lower part of the Sentinel Butte Member. Beds of the zone were mapped in the Glen Ullin (Barclay, 1973) and Dengate quadrangles, and the zone was recognized in parts of the Heart Butte, North Almont, and New Salem quadrangles. The thickest beds of the Spring Valley-Richter zone in the Glen Ullin and Dengate quadrangles are the Spring Valley and Richter beds after which the zone is named. The Spring Valley bed was mined at the Spring
Valley mine in sec. 22, T. 138 N., R. 88 W., Glen Ullin quadrangle. The Spring Valley bed was mapped extensively in the Glen Ullin quadrangle but at only a few places near the west edge of the Dengate quadrangle. The Richter bed was mined at the Richter mine in sec. 13, T. $139 \mathrm{~N}$., R. $88 \mathrm{~W}$., in the northwestern part of the Dengate quadrangle where it is commonly 7-9 feet thick. The Richter bed, or clinker from its in situ combustion, occurs in most areas of the quadrangle except the southeast corner. The Spring Valley and Richter beds are at least partly equivalent and are approximately correlative with Hancock's (1921, p. 13) D bed (Barclay, 1973). The Spring Valley and Richter beds mapped in the Heart Butte area by Stephens" (1970a, b) are in the Spring Valley-Richter zone, although they may not be exactly equivalent to beds of the same names in the Glen Ullin and Dengate quadrangles.

In many parts of the Dengate quadrangle, the Spring Valley-Richter zone does not contain a single thick bed but has two to three lignite beds, 1-4 feet thick, none of which could be traced very far. In some areas where a single Richter or Spring Valley bed was difficult to trace, a thin bed of silicified carbonaceous shale or, less commonly, of carbonaceous shale or lignite which locally appears to merge with the Richter bed was mapped as a marker for the approximate position of the base of the Spring Valley-Richter zone and was named the srl marker bed. In some places a bed of similar lithology near the top of the Spring Valley-Richter zone was mapped and designated the sru marker bed.

In addition to the Tavis Creek, Spring Valley, and Richter beds and the local beds associated with them, several lignite beds, most of which could be traced for only short distances, were mapped. Among these are a local bed generally about 20-30 feet below the Tavis Creek bed, local beds between the Spring Valley-Richter zone and the ws marker bed, and local beds 5-35 feet above the ws marker. The local beds above the ws marker, which occur only on a few of the highest buttes of the area, and the local bed below the Tavis Creek bed appear to belong to persistent intervals of lignite beds that were recognized in the Glen Ullin quadrangle to the west (Barclay, 1973).

The total lignite resources in beds 2.5-10 feet thick within $0-450$ feet of the surface in the Dengate quadrangle are estimated to be 410.83 million short tons, of which the Sentinel Butte Member contains 69.59 million tons and the Tongue River contains 341.24 million tons. Of the total resources in the Sentinel Butte, measured and indicated resources comprise 66.93 million tons and inferred resources comprise 2:66 million tons; of the total resources in the Tongue River, measured and indicated resources comprise 189.87 million tons and inferred resources 151.37 million tons.

PHYSICAL AND CHEMICAL CHARACTERISTICS

The lignite in the Fort Union Formation in the Dengate quadrangle is commonly blackish brown, hard, and woody and is slabby when freshly dug. It characteristically slacks rapidly when exposed to the atmosphere.

Core samples of several lignite beds and of some shale, 
claystone, and siltstone beds associated with a few of the lignite beds were obtained from holes drilled in the Dengate and Glen Ullin quadrangles during a U.S. Geological Survey drilling program in 1966 (Smith, 1970, p. 23-24, 29-33). All analyses of the core samples by the U.S.

Bureau of Mines and the U.S. Geological Survey were reported by Barclay (1971, table 2;1973, table 1). The results of the analyses of core samples of lignite beds in the Dengate quadrangle are presented in table 3 (sheet 2).

Outcrop samples of lignite and various kinds of rocks containing carbonaceous material or plant impressions were collected from the Glen Ullin and Dengate quadrangles during the course of fieldwork by the author and in the summer of 1966 by the author and J. D. Vine, U.S. Geological Survey. Results of the spectrographic, total carbon, and $\mathrm{eU}$ analyses of these samples were reported by Barclay (1971, tables 3,$4 ; 1973$, table 2 ). The results of analyses of two lignite outcrop samples collected in the Dengate quadrangle are presented in table 3, sheet 2, with Vine's permission.

Ash of lignite from the Fort Union Formation is primarily composed of a mixture of sulfates, oxides, and silicates of calcium, silica, aluminum, iron, magnesium, and sodium with much lesser amounts of potassium and a number of minor elements of which the most abundant are commonly titanium, phosphorus, barium, strontium,

'TABLE 4. -- Mercury in drill core samples of lignite beds in the Fort Union Formation, Dengate and Glen Ullin quadrangles, Morton County, N. Dak.

[Analyses by P. R. Norton and Claude Huffman, Jr., U.S. Geological Survey, using the stannous chloride flameless atomic-absorption method employing a $\mathrm{H}_{2} \mathrm{SO}_{4}-\mathrm{KMnO}_{4}$ digestion. Samples with DC numbers are from the Dengate quadrangle and samples with GUC numbers are from the Glen Ullin quadrangle]

\begin{tabular}{|c|c|c|c|c|c|c|}
\hline $\begin{array}{l}\text { Field } \\
\text { No. }\end{array}$ & $\begin{array}{l}\text { Location of } \\
\text { drill hole }\end{array}$ & $\begin{array}{c}\text { Sample } \\
\text { interval } \\
\text { depth }(\mathrm{ft})\end{array}$ & $\begin{array}{l}\text { Bed name and (or) } \\
\text { approximate } \\
\text { stratigraphic } \\
\text { position }\end{array}$ & $\begin{array}{c}\begin{array}{c}\text { Fort Union } \\
\text { Formation }\end{array} \\
\text { Member }\end{array}$ & $\begin{array}{l}\text { USGS } \\
\text { Lab. No. }\end{array}$ & $\begin{array}{c}\mathrm{Hg} \\
(\mathrm{ppm})\end{array}$ \\
\hline DC-1-1a & $\begin{array}{l}\text { NE. cor. } \mathrm{SE}^{1 / 4 \mathrm{SE}^{1 / 4} \mathrm{NE}^{1 / 4}} \\
\text { sec. } 20, \mathrm{~T} .138 \mathrm{~N} . \\
\text { R. } 87 \mathrm{~W} .\end{array}$ & $\begin{array}{c}39.8-41.5 \\
\text { (upper part) }\end{array}$ & $\begin{array}{l}\text { Lower bed of a split Richter } \\
\text { lignite bed (srl bed?). }\end{array}$ & Sentinel Butte. & D 137652 & 0.08 \\
\hline DC-1-1b & -. - -do - . . . . . . - & $\begin{array}{l}39.8-41.5 \\
\text { (lower part) }\end{array}$ & 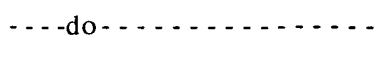 & - . - do - - . - - & D137653 & .18 \\
\hline DC-1-2a & $\ldots$ do $\ldots . . . . .$. & $87.5-92.8$ & Tavis Creek lignite bed. & Tongue River. & D137655 & .16 \\
\hline DC-2-0 & $\begin{array}{l}\text { SE. cor. SW1/4SW1/4 } \\
\text { sec. } 18, T .139 \\
\text { N., R. } 87 \text { W. }\end{array}$ & $54.5-56.3$ & $\begin{array}{l}\text { Top of bed } 64 \text { feet above } \\
\text { base of Sentinel Butte } \\
\text { Member. }\end{array}$ & Sentinel Butte. & D137659 & .05 \\
\hline DC-2-3 & - . - do . . . . . . . . & $166.1-168.5$ & Tavis Creek lignite bed. & Tongue River. & D137665 & .16 \\
\hline DC-2-4 & - do $\ldots$ & $237.6-238.9$ & $\begin{array}{l}\text { Top of bed } 123 \text { feet below } \\
\text { top of Tongue River } \\
\text { Member. }\end{array}$ & ... -do - . . . & D137666 & .12 \\
\hline DC-2-7 & $\ldots$ do $\ldots . . . . .$. & $281.5-283.2$ & $\begin{array}{l}\text { Top of bed } 165 \text { feet below } \\
\text { top of Tongue River } \\
\text { Member. }\end{array}$ & ...-do..... & D137669 & .26 \\
\hline GUC-1-1 & $\begin{array}{l}\mathrm{NE}^{1 / 4 \mathrm{NE}^{1 / 4} \mathrm{SE}^{1 / 4} \mathrm{sec} .} 20 \\
\text { T. } 138 \text { N., R. } 88 \mathrm{~W} .\end{array}$ & $\begin{array}{l}120.0-129.9 \\
\text { (partings removed; } \\
\text { actual thickness } \\
9.0 \mathrm{ft} \text { ). }\end{array}$ & Spring Valley lignite bed. & Sentinel Butte. & D137670 & .43 \\
\hline GUC-2-1 & $\begin{array}{l}\mathrm{SE}^{1 / 4 \mathrm{NE}^{1} / 4} \text { sec. } 32, \text { T.139 } \\
\text { N., R. } 88 \text { W. }\end{array}$ & $162.6-166.4$ & $\begin{array}{l}\text { Top of bed } 188 \text { feet below } \\
\text { top of Tongue River } \\
\text { Member. }\end{array}$ & Tongue River. & D13767i & .10 \\
\hline GUC-3-1 & 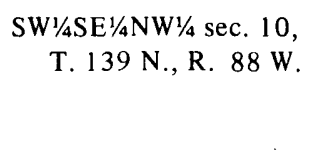 & $65.2-67.3$ & $\begin{array}{l}\text { Haymarsh Creek lignite bed; } \\
\text { top of bed } 21 \text { feet above } \\
\text { base of Sentinel Butte } \\
\text { Member }\end{array}$ & Sentinel Butte. & D137672 & .14 \\
\hline GUC-3-2 & $\begin{array}{l}\mathrm{SW}^{1 / 4} \mathrm{SE} \mathrm{S}^{1} / 4 \mathrm{NW}^{1} / 4 \mathrm{sec} .10 \\
\text { T. } 139 \text { N., R. } 88 \mathrm{~W}\end{array}$ & $85.0-89.6$ & Tavis Creek(?) lignite bed. & Tongue River. & D137673 & .08 \\
\hline
\end{tabular}


boron, copper, and manganese (Sondreal and others, 1968, p. 6-7, 23-24, tables 3,12 ). The compositions of the ash of 18 lignite core samples and of two lignite outcrop samples from the Dengate quadrangle are given in table $3 \mathrm{c}$, sheet 2 , in terms of selected major and minor elements as determined by semiquantitative spectrographic analysis. Omitted were potassium, sodium, silicon, and most of those minor elements not detected in any of the samples. Phosphorus, which has a detection limit of about 0.2 percent in the analytical method used, was looked for but not detected and was omitted from the table. The compositions of the minor elements in the ash of both the lignite core samples and the outcrop samples are similar to compositions reported for Fort Union lignite ash of North Dakota and the east edge of Montana (Zubovic and others, 1961, tables 3, 4; Sondreal and others, 1968, tables 3, 12).

The percentage of sodium in ash has been cited by U.S. Bureau of Mines researchers at Grand Forks, N. Dak., as a useful index of the fouling potential of Fort Union lignite used in many of the large power generating facilities of the Northern Great Plains-Great Lakes region (Gronhovd, 1968, p. 4-5). According to Gronhovd, Harak, and Paulson (1968, p. 77-80), the fouling of convection surfaces and the rate of formation of slag deposits on boiler walls are excessive for lignite with 9 percent $\mathrm{Na}_{2} \mathrm{O}$ in ash. Table $3 \mathrm{~b}$ shows amounts of magnesium, calcium, sodium, and potassium oxides in lignite core samples and, for comparison purposes, in carbonaceous rocks adjacent to a few of the lignite beds. Using the percentage of ash given in table $3 c$, the calculated percentage of sodium oxide in lignite ash ranges from 2.4 percent in $D C-1-1 \mathrm{~b}$ to 16.5 percent in D-2-0 and is more than 9 percent in DC- $1-3,-4$, and -5 and in DC-2-0 and DC-2-3. The sodium content of each of these samples may not be representative of the beds sampled; Gronhovd, Harak, and Paulson (1968, p. 77) reported that sodium content varies markedly from place to place in a single mine.

A portion of each of the lignite core samples used in the chemical analyses was studied by X-ray diffractometer. Both raw lignite and ash produced by low-temperature oxidation of the lignite were used in the study. The lowtemperature ash samples were prepared by I. C. Frost of the U.S. Geological Survey after the method of Gluskoter (1965). Quartz, pyrite, calcite, siderite(?), and clay minerals were the principal minerals detected in most samples. Feldspar occurs in very small amounts in some samples, and heulandite-clinoptilolite(?) was found in sample DC- $1-1 \mathrm{~b}$ in which it is the most abundant mineral present. No mineral containing sufficient sodium to account for the amounts that were detected in the ash could be found in any sample except DC-1-1b, and that sample contained only 2.4 percent sodium in ash. Researchers at the U.S. Bureau of Mines, Grand Forks, N. Dak., who have done considerable work on the composition of Fort Union lignites did not find any sodium-rich minerals in the North Dakota lignite (Spencer, 1969, p. 50) and suggest that the sodium is "probably attached to the coal molecule" (Gronhovd, 1968, p. 5).
Because of the current interest in determining and evaluating possible sources of mercury contamination of the environment, lignite core samples from U.S. Geological Survey drill holes in both the Glen Ullin and Dengate quadrangles were analyzed. The results of the analyses appear in table 4. Ruch, Gluskoter, and Kennedy (1971) reported that a significant amount of mercury in the Illinois coals they sampled is associated with iron sulfide minerals. Diffractometer studies of raw and low-temperature ash samples of some of the lignite core samples listed in table 4 show a good correlation between pyrite and high mercury content of lignite. Samples DC-2-7 and GUC-1-1 which yielded the highest mercury values of the samples analyzed also showed the most intense pyrite lines on diffractograms. The other samples contain small to possibly trace amounts of pyrite.

\section{DEVELOPMENT}

Some lignite beds in the Dengate quadrangle were mined in the past principally for local use, but none of the mines were active during the fieldwork for this report. Mine workings were generally small shallow open pits. The mine on the Tavis Creek bed near the middle of the west edge of sec. 9, T. 138 N., R. 87 W., might have had some underground workings. The largest mine in the area was the Richter mine in the NE $1 / 4$ sec. $13, T .139$ N., R. 88 W.; its last production figures, for the period July 1,1962 , to June 30, 1964, were 6,014 tons, value $\$ 15,425$ (N. Dak. Coal Mine Inspector, 1964, p. 11).

\section{CONSTRUCTION MATERIALS}

\section{GRAVEL}

Gravel in the quadrangle occurs in glacial drift. Some drift gravels, used locally to surface roads, have been quarried in the SE1/4 sec. 7, T. 138 N., R. 87 W., and just beyond the mapped area at the southern end of the deposits in the $\mathrm{SW}^{1} \frac{1}{4} \mathrm{sec} .22$ of the same township.

\section{CLINKER}

Clinker is the baked and fused rock produced by the in situ combustion of coal. The primary cause of in situ burning of lignite in North Dakota is believed to be spontaneous combustion (Blain, 1955, p. 139). Burning in the region probably occured during both Holocene and Pleistocene time (Barclay, 1973). Clinker deposits are extensive and thick in some areas in the northern part of the quadrangle where most of the deposits are associated with the Richter lignite bed. Clinker is used extensively to surface roads.

\section{GANISTER BLOCKS}

Ganister blocks are angular cobble- and boulder-sized blocks and slabs of hard dense silicified siltstone or mudstone that are scattered over the prairie in many parts of the quadrangle and adjacent areas. Areas containing concentrations of scattered ganister blocks are shown on the geologic map. The blocks are generally buff to brownish gray, have a polished appearance on some weathered surfaces, and characteristically contain tubular plant molds. Some of the blocks may be glacial erratics or lag deposits of glacial drift. Some of the dirft contains angular cobble- 
and pebble-sized fragments of ganister, and in some areas scattered pebbles and boulders of igneous and metamorphic rocks occur with concentrations of ganister blocks. The ganister blocks in the quadrangle were probably originally derived from beds in the Fort Union Formation (Denson and Pipiringos, 1969, p. 15; Barclay, 1973).

In North Dakota ganister blocks have been widely used for riprapping earthfill dams, water diversion channels, and river banks.

\section{OIL AND GAS}

No test wells for oil and gas have been drilled in the Dengate quadrangle. The closest producing well is about 28 miles west in sec. 15, T. 137 N., R. 92 W., Stark County, where Texaco, Inc. recovered 203, 454 barrels of oil as of July 1, 1971, from the Upper Ordovician Red River Formation at a depth of more than 10,000 feet (N. Dak. Geological Survey, 1972, p. 44). Rocks at depth in the quadrangle are valuable prospectively for oil and gas. The sedimentary section underlying the area is probably more than 10,000 feet thick (Hansen, 1957). It includes formations of Ordovician through Permian age (Anderson and Mendoza, 1960), some of which have produced oil in other parts of the Williston basin in North Dakota $(\mathrm{N}$. Dak. Geological Survey, 1972).

\section{REFERENCES CITED}

Anderson, S. B., and Mendoza, H. A., 1960, Pre-Mesozoic paleogeologic map of North Dakota: N. Dak. Geol. Survey Misc. Map 7.

Barclay, C. S. V., 1971, Preliminary geologic map of the Dengate quadrangle, Morton County, North Dakota: U.S. Geol. Survey open-file map.

1974, Geologic map and lignite deposits of the Glen Ullin quadrangle, Morton County, North Dakota: U.S. Geol. Survey Coal Inv. Map C-54.

Benson, W. E., 1953, Geology of the Knife River area, North Dakota: U.S. Geol. Survey open-file report, 323 p., also Ph.D. thesis, Yale Univ.

Blain, W. S., 1955, "Scoria" of North Dakota: N. Dak. Geol. Survey Bull. 28, p. 138-143.

Brown, R. W., 1962, Paleocene flora of the Rocky Mountains and Great Plains: U.S. Geol. Survey Prof. Paper $375,119 \mathrm{p}$.

Carlson, C. G., compiler, 1969, Bedrock geologic map of North Dakota: N. Dak. Geol. Survey Misc. Map 10.

Colton, R. B., Lemke, R. W., and Lindvall, R. M., 1963, Preliminary glacial map of North Dakota: U.S. Geol. Survey Misc. Geol. Inv. Map I-331.

Croft, M. G., 1970, Ground water basic data, Mercer and Oliver Counties, North Dakota - Pt. 2, Ground water basic data: N. Dak. Geol Survey Bull. 56, pt. 2 (N. Dak. Water Comm. County Ground Water Study 15, pt. 2), 268 p.

Denson, N. M., and Pipiringos, G. N., 1969, Stratigraphic implications of heavy-mineral studies of Paleocene and Eocene rocks of Wyoming, in Wyoming Geol. Assoc. Guidebook 21 st Ann. Field Conf., Symposium on Tertiary rocks of Wyoming, 1969: p. 9-18.

Fenneman, N. M., 1931, Physiography of western United States: New York, McGraw-Hill Book Co., Inc., 534 p.
Gluskoter, H. J., 1965, Electronic low-temperature ashing of bituminous coal: Fuel, v. 44, no. 4, p. 285-291.

Gronhovd, G. H., 1968, Progress and problems in combustion of lignite from the northern Great Plains area ipreprint]: New York, Soc. Mining Engineers, AIME, $15 \mathrm{p}$.

Gronhovd, G. H., Harak, A. E., and Paulson, L. E., 1968, Ash fouling studies of North Dakota lignite: U.S. Bur. Mines Inf. Circ. 8376, p. 76-94.

Hancock, E. T., 1921, The New Salem lignite field, Morton County, North Dakota: U.S. Geol. Survey Bull. 726-A, p. 1-39.

Hansen, Miller, 1957, Structure map on pre-Cambrian [North Dakota] : N. Dak. Geol. Survey Misc. Map 5.

Hennen, R. V., 1943, Tertiary geology and oil and gas prospects in Dakota basin of North Dakota: Am. Assoc. Petroleum Geologists Bull., v. 27, no. 12, p. 1567-1594.

Hickey, L. J., 1969, Stratigraphy of the Golden Valley Formation of western North Dakota [abs.] : Geol. Soc. America Abs. with programs for November 1969, p. 100.

Laird, W. M., and Mitchell, R. H., 1942, The geology of the southern part of Morton County, North Dakota: N. Dak. Geol. Survey Bull. 14, 42 p.

Leffingwell, H. A., 1971, Palynology of the Lance (Late Cretaceous) and Fort Union (Paleocene) Formations of the type Lance area, Wyoming, in Symposium on palynology of the Late Cretaceous and early Tertiary: Geol. Soc. America Spec. Paper 127, p. 1-64.

Leonard, A. G., 1916, Pleistocene drainage changes in western North Dakota: Geol. Soc. America Bull., v. 27 , p. 295-304.

North Dakota Coal Mine Inspector, 1964, First biennial report, July 1, 1962-June 30, 1964: Bismarck, N. Dak. Coal Mine Inspection Dept., 19 p.

North Dakota Geological Survey, 1972, Production statistics and engineering data; oil in North Dakota, last half 1971: Grand Forks, N. Dak. Geol. Survey, 277 p.

Royse, C. F., Jr., 1967, Tongue River-Sentinel Butte contact in western North Dakota: N. Dak. Geol. Survey Rept. Inv. $45,53 \mathrm{p}$.

1970, A sedimentologic analysis of the Tongue River-Sentinel Butte interval (Paleocene) of the Williston Basin, western North Dakota: Sedimentary Geology, v. 4 , no. 1, p. 19-80.

Ruch, R. R., Gluskoter, H. J., and Kennedy, E. J., 1971, Distribution of mercury in Illinois coals [abs.]: Geol. Soc. America Abs. with programs for November 1971, p. 691-692.

Seager, O. A., and others, 1942, Stratigraphy of North Dakota: Am. Assoc. Petroleum Geologists Bull., v. 26, no. 8, p. 1414-1423.

Smith, H. L., 1970, Preliminary description of cores, chemical analysis of lignite beds, and map showing locations of holes drilled in Grant, Hettinger, Morton, and Stark Counties, North Dakota: U.S. Geol. Survey open-file report, $43 \mathrm{p}$.

1973, Geologic map and lignite deposits of the New Salem quadrangle, Morton County, North Dakota: U.S. Geol. Survey Coal Inv. Map C-62. 
Sondreal, E. A., Kube, W. R., and Elder, J. L., 1968, Analysis of the Northern Great Plains Province lignites and their ash: a study of variability: U.S. Bur. Mines Rept. Inv. 7158, 94 p.

Spencer, J. D., 1969, Review of Bureau of Mines coal Program, 1968: U.S. Bur. Mines Inf. Circ. 8416, 94 p.

Stephens, E. V., 1970a, Geologic map of the Heart Butte NW quadrangle, Morton and Grant Counties, North Dakota: U.S. Geol. Survey Coal Inv. Map C-52. 1970 b, Geologic map of the Heart Butte quadrangle, Morton and Grant Counties, North Dakota: U.S. Geol. Survey Coal Inv. Map C-53.
Tisdale, E. E., 1941, The geology of the Heart Butte quadrangle: N. Dak. Geol. Survey Bull. 13, 32 p.

Trapp, Henry, Jr., 1971, Ground-water basic data, Hettinger and Stark Counties, North Dakota: North Dakota Water Comm. County Ground Water Study 16, pt. 2, 455 p. .

Zubovic, Peter, Stadnichenko, Taisia, and Sheffey, N. B., 1961, Geochemistry of minor elements in coals of the Northern Great Plains coal province: U.S. Geol. Survey Bull. 1117-A, p. A1-A58. 